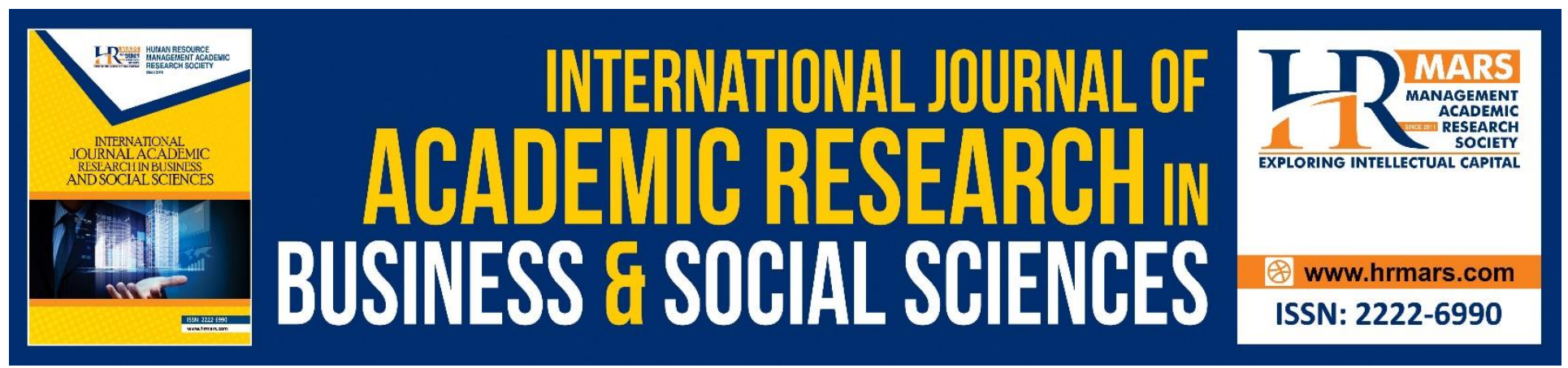

\title{
Issues and Trends in Open Innovation amongst Malaysian Fintech Start-ups
}

Misyer Mohamed Tajudin and Normaziah Che Musa

To Link this Article: http://dx.doi.org/10.6007/IJARBSS/v8-i9/4874 $\quad$ DOI: $10.6007 /$ IJARBSS/v8-i9/4874

Received: 22 August 2018, Revised: 17 Sept 2018, Accepted: 29 Sept 2018

Published Online: 09 October 2018

In-Text Citation: (Tajudin \& Musa, 2018)

To Cite this Article: Tajudin, M. M., \& Musa, N. C. (2018). Issues and Trends in Open Innovation amongst Malaysian Fintech Start-ups. International Journal of Academic Research in Business and Social Sciences, 8(9), 1949-1964.

Copyright: (C) 2018 The Author(s)

Published by Human Resource Management Academic Research Society (www.hrmars.com)

This article is published under the Creative Commons Attribution (CC BY 4.0) license. Anyone may reproduce, distribute, translate and create derivative works of this article (for both commercial and non-commercial purposes), subject to full attribution to the original publication and authors. The full terms of this license may be seen

at: http://creativecommons.org/licences/by/4.0/legalcode

Vol. 8, No. 9, September 2018, Pg. 1949 - 1964

http://hrmars.com/index.php/pages/detail/IJARBSS

JOURNAL HOMEPAGE

Full Terms \& Conditions of access and use can be found at http://hrmars.com/index.php/pages/detail/publication-ethics 


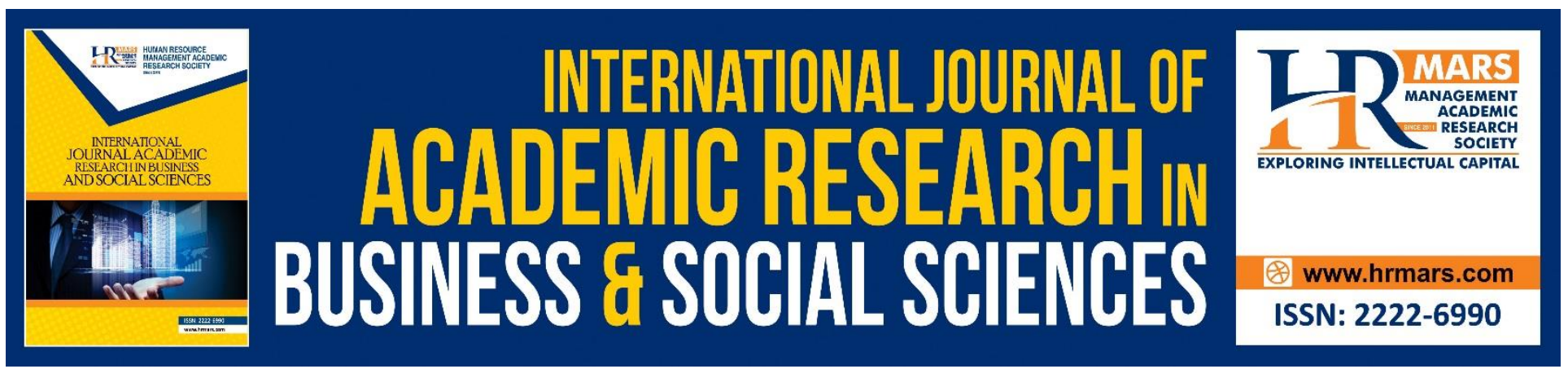

\title{
Issues and Trends in Open Innovation amongst Malaysian Fintech Start-ups
}

\author{
Misyer Mohamed Tajudin and Normaziah Che Musa \\ Faculty of Business and Technology, UNITAR International University, Malaysia
}

\begin{abstract}
This research explores the concept of open innovation within the Malaysian fintech industry and explores its antecedents and the ways they influence the open innovation process. More specifically, the study centers on the relationships between market orientation and open innovation process in Malaysian fintech start-ups. It is theorized that earlier involvements amongst majority of fintech start-ups in incubator programmes, start-up bootcamps or kickstarter challenge help to build their market orientation and open innovation capabilities in creating, acquiring, assimilating, and exploiting knowledge within open innovation ecosystems that will produce more knowledge resources, translating into new potential sources of revenue for the firm, and creating continual variations across firms. Success in open innovation may support Malaysia's aim to become the leading hub for fintech innovation and investment in the region.
\end{abstract}

Keywords: Open Innovation, Market Orientation, Fintech, Start-Ups

\section{Introduction}

Increasingly in business, our lack of clear consensus around the best ways to foster and scale new ideas has seen it evolving along a broad spectrum between closed and open innovation. Innovation studies have shown keen interest towards open ecosystem and organizational network view of strategy and innovation (Usman, Roijakkers, Vanhaverbeke \& Frattini, 2018), although strategic analysis and innovation at the company and industry levels remain highly relevant and robust, perhaps due to the dynamics in the business environment that are forcing firms to consider collaborating to innovate at the expense of competing against each other (Rigby \& Zook, 2002; Christensen, Olesen \& Kjær, 2005). Firms have been engaging in knowledge transfers, joint ventures, strategic alliances and other collaborative efforts to innovating even before the term open innovation is introduced. However, Chesbrough (2003; 2006), Enkel, Gassmann and Chesbrough (2009), and Chesbrough and Bogers (2014) present open innovation as one of the most comprehensive descriptions of a distributed innovation approach, which assumes that firms can and should use external ideas as well as internal ideas, and internal and external paths to market, as the firms look to advance their technology and offerings. Such collaborative innovation initiative allows internal and 
external ideas to flow between organizational boundaries, governed by suitable business models and intellectual property agreements. Its universal appeal and relevance, despite the criticisms against it (Trott \& Hartmann, 2009), has attracted various organizations of all sizes from different economies around the world to embark on it in anticipation of positive innovation outcomes. While already prevalent mostly in the developed world, the idea of open innovation is slowly being embraced by developing nations like Malaysia to supplement its limitations in R\&D capabilities (Malaysia Economic Monitor, April 2012) and lack of technological knowledge (Comin, 2014), while overcoming its continual inefficient innovator label (the country was ranked 46 last year but fell to 48 in the innovation efficiency ratio this year in the Global Innovation Index, way behind Vietnam at $16^{\text {th }}$ and Thailand at $\left.33^{\text {rd }}\right)$. In a preliminary research on open innovation in the country, Naqshbandi and Kaur (2011) indicated that a number of Malaysia firms were already implementing the open innovation process especially amongst SMEs particularly by collaborating with their suppliers and customers. Over the years, the adoption of open innovation process in Malaysia has grown significantly (National Survey of Innovation 2012; 2015), but ultimately more research needs to be conducted in this fertile area of study to offer better understanding of the mechanisms behind effective open innovation process that can churn positive prospects for Malaysia.

\section{Issues in Open Innovation}

Greater domestic and global competition, continuous development of new technologies, constantly changing customer needs, shorter product life cycles, the emerging service economy and rising costs place organizations under constant pressure to innovate as they meet time, budget, and performance requirements as well as to advance, compete and differentiate themselves successfully in the marketplace (Baregheh, Rowley \& Sambrook, 2009).

What seems lacking in the closed innovation paradigm can be compensated by open innovation, which presents an integrative view of all forms of distributed innovation by opening up the innovating process to selected outsider firms in pursuit of enlarged opportunities to innovate and commercialize. This change in paradigm has been fueled by social factors like the increasing labor mobility among highly skilled workers, economic factors such as the access to venture capital (Chesbrough, 2003), and firm strategies, like the division of research work in increasingly specialized departments (Langlois, 2003). Likewise, different forms of collaborative innovation have emerged over the years to provide remedy for the limitations in closed innovation process, as depicted in Table 1. 
INTERNATIONAL JOURNAL OF ACADEMIC RESEARCH IN BUSINESS AND SOCIAL SCIENCES Vol. 8, No. 9, Sept. 2018, E-ISSN: 2222-6990 @ 2018 HRMARS

Table 1. Evolution of Distributed Innovation Approaches

\begin{tabular}{|c|c|c|c|}
\hline Year(s) & Name of scholar(s) & Country(ies) & Contributed Idea \\
\hline \multirow{3}{*}{$1850 s$} & \multirow{3}{*}{ Friedrich List } & Germany & $\begin{array}{l}\text { National system for } \\
\text { Economic Development }\end{array}$ \\
\hline & & Japan & $\begin{array}{l}\text { International Economic } \\
\text { Policy of the Meiji Japan }\end{array}$ \\
\hline & & China & $\begin{array}{l}\text { Deng Xiaoping's Post-Mao } \\
\text { policies }\end{array}$ \\
\hline 1899 & Marshall & England & Industry agglomeration \\
\hline 1950 & Dahmén & Sweden & Development blocks \\
\hline 1959 & Carter and Williams & USA & $\begin{array}{l}\text { Incoming information quality } \\
\text { for innovation }\end{array}$ \\
\hline 1969 & Allen & USA & $\begin{array}{l}\text { Gatekeepers' role to ensure } \\
\text { good external linkages for } \\
\text { innovation }\end{array}$ \\
\hline 1976 & von Hippel & USA & User innovation \\
\hline 1979 & Pearson, Green and Ball & USA & Increasing R\&D projects \\
\hline $1980 s$ & Freeman and Lundvall & Nordic countries & $\begin{array}{l}\text { National system of } \\
\text { innovation }\end{array}$ \\
\hline 1985 & Rothwell and Zegveld & USA & $\begin{array}{l}\text { Network model of } \\
\text { innovation, }\end{array}$ \\
\hline 1988 & von Hippel & USA & Distributed innovation \\
\hline 1991 & Porter & USA & $\begin{array}{l}\text { Diamond model of Michael } \\
\text { Porter for the Competitive } \\
\text { Advantage of Nations }\end{array}$ \\
\hline 1993 & Tidd & USA & $\begin{array}{l}\text { Interorganizational and } \\
\text { intraorganizational } \\
\text { innovation }\end{array}$ \\
\hline 1995 & Etzkowitz and Leydesdorff & USA & $\begin{array}{l}\text { Triple Helix Innovation } \\
\text { Theory }\end{array}$ \\
\hline 2003 & Chesbrough & USA & Open Innovation \\
\hline 2005 & von Hippel & USA & Democratizing innovation \\
\hline 2007 & Mulgan, Tucker, Ali and Sanders & USA & Social innovation \\
\hline 2007 & Berkhout & USA & Cyclic Innovation Model \\
\hline 2009 & Carayannis and Campbell & USA & $\begin{array}{l}\text { Quadruple Helix Innovation } \\
\text { Theory }\end{array}$ \\
\hline 2010 & Adner and Kapoor & USA & Innovation ecosystems \\
\hline
\end{tabular}


INTERNATIONAL JOURNAL OF ACADEMIC RESEARCH IN BUSINESS AND SOCIAL SCIENCES Vol. 8, No. 9, Sept. 2018, E-ISSN: 2222-6990 @ 2018 HRMARS

In understanding the knowledge transfer phenomena in an open innovation context where diverse multiple helix stakeholders are interacting between universities and its constituent stakeholders in pursuit of open innovation and commercialization, Miller, McAdam, Moffett, Alexander and Puthusserry (2016) identify five factors, namely human centric factors, organizational factors, knowledge characteristics, power relationships and network characteristics, which mediate both the ability of stakeholders to engage in knowledge transfer and the effectiveness of knowledge acquisition, assimilation, transformation and exploitation. Open innovation efforts may subscribe to these same rules of engagement.

The analysis by Aspenberg and Kumlin (2012) on European open innovation ecosystems shows that the output of an open innovation arena depends on whether the partner organizations are devoted to the work, and whether there is a flow of knowledge and ideas between the arena and the partners. This implies that the success of open innovation initiatives is dependent on their surrounding organizations and actors.

When it comes to well-developed nations, most big, medium and small business organizations are already engaging in some form of collaborative innovation, or open innovation. This different innovation model concerns a systematic process where ideas can pass to and from different organizations and travel on different exploitations vectors for value creation. In their executive survey of 125 large firms (with annual sales in excess of US\$250 million and having more than 1000 workers) from the US and Europe, Chesbrough and Brunswicker (2013) found that $78 \%$ are practicing open innovation, largely involving customer co-creation, informal networking, and university grants to collaboratively innovate. The typical large firm in their sample spends US\$ 2 million annually on open innovation, and employs 20 full time equivalent people to do the work.

In terms of the emerging economies, Fu and Xiong (2011) investigated open innovation in China and found that Chinese firms have in practice employed a variety of open innovation models since the mid-1980s. Policies introduced by the Chinese government to reform its science and technology system through acquisition of foreign technology, industry-university collaboration and the 'go global' strategy have in particular encouraged Chinese firms to adopt certain types of open innovation model. As a result, many transnational corporations from developed economies are increasingly globalizing their innovation activities (Ernst, 2006) and actively entering Chinese market to source low-end value chain activities and also seeking plentiful R\&D knowledge and human capital (Fu \& Gong, 2010). On the other hand, more and more indigenous firms are attempting to go abroad to globalize themselves to acquire external $R \& D$ resources and improve innovation capabilities. Some have emerged as major players in certain technology intensive sectors (Mathews, 2002), especially after the financial crisis and economic recession in developed countries.

In spite all of these, open innovation appears to be more important for SMEs than large firms as they are collaborating more frequently with external innovation partners and alliance networks than their larger competitors based on large-scale surveys by Edwards, Delbridge and Munday (2005) and Vanhaverbeke (2012), especially in the wake of today's challenging market conditions. The economic downturn has weakened the financial conditions of many small and medium-sized firms (SMEs), especially in industries in which foreign, low-cost producers are readily available to threaten the incumbents' survival. Meanwhile, certain high-tech start-ups may have internal cutting-edge technology, but lack the manufacturing capabilities or distribution channels to turn it into success. At 
the same time, other SMEs may face several constraints in product differentiation, apart from lacking the required internal financial resources and technical capabilities altogether. All of these changing market conditions are forcing these SMEs to collaborate with external partners in order to adapt or reinvent their businesses through new technologies or unique value propositions.

These same phenomena may have been the impetus for the birth of many fintech start-ups that have spawned in number since a few years ago. This new industry represents the segment of the technology scene that is revolutionizing the design and delivery of financial services to meet the consumer needs for transparency, convenience, personalization, security, simplicity and effectiveness amid the dwindling trust towards traditional financial institutions after the 2008 global financial crisis as well as the emergence of the on-demand services that largely operate on the ubiquitous mobile application platforms. Although at its infancy stage in Malaysia as compared to its counterparts in China, the US and Europe, these Malaysian fintech start-ups should form a potent point of research interest in open innovation because most are also known to engage in some forms of open innovation, especially through networks built during their earlier participation in incubator programs, start-up bootcamps and idea competitions.

\section{Current innovation trends in the Fintech Industry}

"Fintech", short for financial technology, refers to the use of technology to deliver faster and cheaper financial services application information the emergence of cashless societies around cosmopolitan cities around the world Fintech stands to capture a significant portion of market share away from traditional financial service providers, who have been slow in innovating (Reidenbach \& Moak, 1986; Naslund, 1986; Reidenbach \& Grubbs, 1987) due to the general perception that new financial services cannot be patented and can easily be imitated, thus making little economic sense to innovate.

This current inclination towards technology in financial services resonates the findings by earlier scholars such as Barras (1986, 1990), Huete and Roth (1988), and Sundbo (1991) who conclude that innovations in the industry have become increasingly technological since the 1980s with the introduction of computer-based self-service systems (ATMs) and the use of electronic data processing (EDP) to curb imitation. Storey and Easingwood (1999), Fincham, Fleck, Procter, Tiemey, Williams and Scarbrough (1995) also emphasize that technology advantage in financial services must align with the firm's strategy to succeed in the market.Fintech is destined to take a big chunk of business away from traditional service providers, who have been slow in innovating (Reidenbach and Moak, 1986; Naslund, 1986Fintech is destined to take a big chunk of business away from traditional service providers, who have been slow in innovating (Reidenbach and Moak, 1986; Naslund, 198

Mostly established by smaller and nimbler startups, the fintech sector exceeds expectations as global transaction figure reached US\$769.3 billion in 2014 (Statista, 2015), and global investments have grown exponentially from US\$1.8 billion in 2010 to US\$19 billion in 2015 (Citi Group, 2016). The number of global fintech startups have also doubled from 2013 to 2014 (Global Banking Practice, McKinsey \& Co., Dec 2015) with each competing for a share in its very own niche, and most of the time with a digital-only focus. These non-bank challengers are operationally built for continuous innovation, and frequently upgrade their arsenal of IT tools, strategies, and skilled personnel (Omni Channel Banking: The Digital Transformation Roadmap; Efma \& Backbase, 2015). 
INTERNATIONAL JOURNAL OF ACADEMIC RESEARCH IN BUSINESS AND SOCIAL SCIENCES Vol. 8, No. 9, Sept. 2018, E-ISSN: 2222-6990 @ 2018 HRMARS

Malaysia's fintech presence is still nascent and small if compared to its counterparts in the US, Europe and other bigger economies of the world. However, developments in the domestic financial landscape have created the right impetus for its potential growth. Since 2014, the Malaysian Securities Commission has been supporting the development in Malaysia fintech industry by being the first country in the Asian region to establish a regulatory framework for equity crowd funding, enabling entrepreneurs to sell equity to investors aimed at assisting small businesses in terms of funding. Their funding needs are largely unserved and underserved in the current capital market. By2015 Malaysia has become the first Asia Pacific country to legislate a legal framework for equity crowdsourcing with the Central Bank's commitment to formulate a framework that "encourages innovation without undermining financial stability, the integrity of the financial system or the adequate protection for financial consumers." These moves, among others, have led to a projected growth of a staggering US\$14, 4439.6mil by 2020 (Statista, 2016), reflecting the country's potential as a major fintech center, supported by its proximity to a large customer base of international financial institutions and end users with high levels of digital adoption and internet penetration. Furthermore, Malaysia is strongly connected within the US\$2 trillion of global Islamic finance market and was ranked 9th globally in financial market development by the World Economic Forum in 2015/2016.

Key growth areas in the fintech industry include alternative financing through peer-to-peer lending and merchant financing (representing the Malaysian market's largest segment), equity crowdfunding, invoice factoring platforms, automated investment services, digital currencies which operate independent of any central authority or banks, payment and remittance systems which bypass traditional banking channels, forex and cross-border fund transfers / remittance, blockchain, artificial intelligence and biometric applications, and the use of big data and analytics to maximize available customer data to further leverage on customer relationships.

Increasingly, these developments have benefited from the interaction between start-ups and various industry stakeholders to integrate their internal R\&D efforts with gathering external knowledge from other sources (Chesbrough, 2006). This echoes the shift towards the open ecosystem view of strategy and innovation, which is fueled by changing social factors like the increasing mobility of the labor force especially among highly skilled workers, economic factors such as the access to venture capital (Chesbrough, 2003), the evolving firm strategies, like the division of research work in increasingly specialized departments, as well as the advancement in information and communications technology that promotes sharing of ideas, leading to collaborative initiatives that are democratizing innovation (von Hippel, 2005). A significant number of fintech start-ups in Malaysia, for instance, work alongside industry stakeholders (customers, competitors, suppliers, regulators, universities / research labs, consultants and industry association), like other global players who are actively working together in innovation labs, as well as participating in startup bootcamps or idea competitions in pursuit of the next breakthrough in financial services, as well as the monetary rewards that follow. These forms of collaborative networks, temporary organizations (Ahuja, 2000) or open innovation collaborations (Yström, Ollila, Fredberg, \& Elmquist, 2010) also emphasize the collective interest to be part of developing better and faster platforms to drive firm productivity and enhance the customer 
INTERNATIONAL JOURNAL OF ACADEMIC RESEARCH IN BUSINESS AND SOCIAL SCIENCES Vol. 8, No. 9, Sept. 2018, E-ISSN: 2222-6990 @ 2018 HRMARS

experience, especially in banking and finance.Increasingly, these developments have benefited from the interaction between startups and social factors like the increasing labor mobility among highly skilled workers, economic factors such as the access to venture capital (Chesbrough, 2003), the evolving firm strategies, like the division of research work in increasingly specialized departments, as well as the advancement in information and communications technology that promotes sharing of ideas, leading to collaborative initiatives that are democratizing innovation (von Hippel, 2005). A significant number of fintech startups in Malaysia, for instance, work alongside industry stakeholders (customers, competitors, suppliers, regulators, universities / research labs, consultants and industry association), like other global players who are actively working together in innovation labs, as well as participating in startup bootcamps or idea competitions in pursuit of the next breakthrough in financial services, as well as the monetary rewards that follow. These forms of collaborative networks, temporary organizations (Ahuja, 2000) or open innovation collaborations (Yström, Ollila, Fredberg, \& Elmquist, 2010) also emphasize the collective interest to be part of developing better and faster platforms to drive productivity and enhance the customer experience in banking and finance comprehensively.

The critical ways that these start-ups and their innovation partners put their creativity to ideation, development and followed by commercialization highlight the importance of the open innovation processes they go through. Yet, this collaborative process has historically been wrought with problems resulting in most traditional financial institutions still being slow and hesitant to collaborate and forced to keep a balance between being open and closed to cooperation with external parties in innovating (Martovoy \& Mention, 2016). In Malaysia, however, the transition towards an open innovation ecosystem following recommendations by various research work has been smooth, displaying potent movements along the right trajectory, as evident in Table 2.

Table 2. National Survey of Innovation 2012 - 2015

\begin{tabular}{|l|c|c|c|c|c|c|c|c|}
\hline & \multicolumn{4}{|c|}{ Manufacturing } & \multicolumn{4}{c|}{ Services } \\
\hline & \multicolumn{2}{|c|}{ New Product } & $\begin{array}{c}\text { Improved } \\
\text { Product }\end{array}$ & \multicolumn{2}{c|}{ New Service } & $\begin{array}{c}\text { Improved } \\
\text { Service }\end{array}$ \\
\hline Year & 2012 & 2015 & 2012 & 2015 & 2012 & 2015 & 2012 & 2015 \\
\hline Closed Innovation & $82 \%$ & $24 \%$ & $78 \%$ & $30 \%$ & $80 \%$ & $33 \%$ & $83 \%$ & $23 \%$ \\
\hline Joint Innovation & $17 \%$ & $36 \%$ & $20 \%$ & $34 \%$ & $15 \%$ & $34 \%$ & $13 \%$ & $38 \%$ \\
\hline Open Innovation & $1 \%$ & $40 \%$ & $2 \%$ & $36 \%$ & $5 \%$ & $33 \%$ & $4 \%$ & $39 \%$ \\
\hline
\end{tabular}

In 2012, approximately $80 \%$ of all innovative output (combining new and improved products and services) were the result of closed innovation, while in 2015 it fell to less than $30 \%$ in both manufacturing and services. The major reasons behind this buoyant adoption involve the government's readiness to develop the effective innovation ecosystem that encourages joint and 
INTERNATIONAL JOURNAL OF ACADEMIC RESEARCH IN BUSINESS AND SOCIAL SCIENCES Vol. 8, No. 9, Sept. 2018, E-ISSN: 2222-6990 @ 2018 HRMARS

open innovations to thrive. Such initiative, while still undergoing trials and improvements, are perceived as sufficient to counter the earlier factors that suppressed collaborative innovation including inadequate IP (intellectual property) management at the policy level, at research institutions and in industries at large (Ismail, Yussuf \& Zulkifli, 2017), which are going to affect the growth of new sectors. The proliferation of new industries like fintech in the country is testament to the perceptions that the Malaysian business landscape is now ready to embrace open innovation through ample and strategic support from various stakeholders that range from government ministries and agencies, universities and research institutions, suppliers, consumers, employees, business clusters, entrepreneurs and financiers.

Investigations of innovation in financial service firms have been undertaken by earlier researchers (Gadrey, Gallouj, Lhuillery \& Weinstein, 1994; Sundbo, 1997) who witness innovation activities being spread out throughout many of these organizations but whose innovation process is neither systematic and efficient with mobilizing external parties, nor in getting customers to be involved in the innovation process. Sundbo (1994) conclude that most service firms generate innovative ideas unexpectedly, especially through informal contacts in other firms (Berg \& Naslund, 1988) and customers were not systematically involved until the testing of the prototype. Once ideas were finalized, a larger part of the organization becomes involved in the whole planning, testing, developing and decision-making processes within the frames of the company strategy. In a nutshell, the innovation process in financial service firms can be divided into three phases, namely Ideation, Development and Commercialization (Flores, Belaud, Le Lann \& Negny, 2015). It remains paramount for fintech start-ups to apply the right open innovation process that can result in successful financial services in the market.

\section{Antecedents of Open Innovation}

Although open innovation has gained prominence and has been promoted as the way to go for startups and the rest in achieving sustainable growth, yet no consensus has been found on its antecedents. It is crucial to consider the prerequisites for successful open innovation as compared to closed innovation (Herzog \& Leker, 2010). The transparent organizational boundaries inherent in open innovation enables in- and outflow of innovative ideas and competencies amongst members to foster innovation, although further empirical research is required (Lazzarotti \& Manzini, 2009). Similar studies on factors that promote innovation in various closed innovation initiatives have been conducted, but is still in its infancy within open innovation ecosystems that involves partners from industry, society and academia working together in knowledge creation (Ollila \& Elmquist, 2011).

Further exploration from an open innovation setting will enhance our understanding of the mechanism at play (Yström, Aspenberg \& Kumlin, 2012). The implications of these new product alliances for both society in general, and firms in particular, are also largely unknown. The role of customers, for instance, in new service developments has been covered significantly by extant research but its implications and process are found to be vague (De Smet, Mention \& Torkkeli, 2016). Such heterogeneity in the characteristics of the samples and of the independent variables, coupled 
INTERNATIONAL JOURNAL OF ACADEMIC RESEARCH IN BUSINESS AND SOCIAL SCIENCES Vol. 8, No. 9, Sept. 2018, E-ISSN: 2222-6990 @ 2018 HRMARS

with the relative approaches used in previous research have contributed to the lack of agreement, in generic terms, on the impact of various antecedents of open innovation on innovation performance (Greco, Grimaldi \& Cricelli, 2015). Hence, capturing the multifaceted nature of open innovations would require studies incorporating multiple contexts.

Some recent studies have shown that open innovation is influenced by market information management capabilities of the service provider (Rubera, Chandrasekaran \& Ordanini, 2016; Arrigo, 2018), in conjunction with the synonymous "market orientation" term that has been found to affect innovation processes (Vorhies \& Morgan, 2005; Narasimhan, Rajiv \& Dutta, 2006; De Luca \& Atuahene-Gima, 2007). Extant research on market-oriented companies have shown how most are no longer subjected to the classical view of depending on in-house innovation as they become more receptive to the outside environment in regard to innovating, consequently developing competences that match and integrate internal and external resources that have positive implications on innovation performance.

\section{Conclusion and Future Agenda}

The establishment of open innovation and its coincidental correlation to the mounting interest from the industry to embrace collaboration, organizational agility, flexibility and outsourcing, as well as the increasingly networked world (Huizingh, 2010; Huggins \& Thompson, 2015; Popa, Soto-Acosta \& Martinez-Conesa, 2017) has made it a hugely popular research topic since the start of the new millennium (Carayannis \& Campbell, 2011; Spithoven, Vanhaverbeke \& Roijakkers, 2013). However, significant gaps exist including the scarcity of non-Western perspectives in researches related to the antecedents and implications of open innovation process. Therefore, as major theories have been developed based on Western / developed nations' perspectives (Huston \& Sakkab, 2006), which originally focused on the study of high-tech industries ranging from agro-biotechnology, pharmaceuticals to information and telecommunication technologies (West \& Gallagher, 2006), a shift in perspective towards Malaysia as an Asian developing economy should be a welcoming effort in the right direction in furthering knowledge of this research area. Applicability of the extant theories in open innovation to the Malaysian ecosystem will be tested considering differences in terms of economic and political structure, regulation aspect, intellectual property law, capital markets and industry structure, competitive environment and the people/cultural elements (West, Vanhaverbeke \& Chesbrough, 2006; Yoon \& Lee, 2005).

The context of this study in untested territory, amongst Malaysian fintech start-ups is also very relevant as extant research on open innovation have focused on high-tech large firms, although recent studies have included SMEs (Laursen \& Salter, 2006; Van de Vrande, De Jong, Vanhaverbeke \& De Rochemont, 2009). Fintech start-ups, being part of knowledge-intensive business services (KIBS) that are central actors in intellectual capital development (Smedlund \& Toivonen, 2007), shall also provide a fertile ecosystem for this area of research. It is hoped that by bridging this contextual gap, it would enhance our understanding of antecedents to open innovation in the Malaysian fintech 
INTERNATIONAL JOURNAL OF ACADEMIC RESEARCH IN BUSINESS AND SOCIAL SCIENCES Vol. 8, No. 9, Sept. 2018, E-ISSN: 2222-6990 @ 2018 HRMARS

context, as an emerging industry within a developing economy landscape, subsequently adding to the prevailing body of knowledge.

Duarte and Sarkar (2011) in their study to form a taxonomy for open innovation find that most research were conducted using case studies, whose results were subjective, many of which were limited to a specific industry, a region, or a nation. Comparative studies in open innovation are also still uncommon, and theory development has ample opportunity to be extended. This deficiency in research methodology calls for extensive studies to scientifically investigate the open innovation paradigm (Reibstein, Day \& Wind, 2009). Future research in this area should aim to fill in this methodological void by carrying out a survey via a multidimensional measurement approach consisting of administering questionnaire and interview sessions involving critical managers at Malaysian fintech start-ups, which shall be obtained through their membership with the Fintech Association of Malaysia (FAOM) and their record in the Fintech Malaysia Report 2017. Such research design and methodology are hoped to generate meaningful results in this discipline as well as create pathways for future studies.

Future research must also aim to address several theoretical gaps in the literature that hinder our current comprehension of open innovation. One of them concerns the lack of a proper definition of open innovation, which has been linked with other similar types of innovation, such as collaborative or distributed innovation, or are focusing on particular aspects of innovation collaborations, such as user innovation (von Hippel, 2005). Dahlander and Gann (2010) acknowledge similar difficulty to describe the terminologies used and engage on a systematic review of extant literature on open innovation in order to "clarify the definition of openness". Since the fintech industry epitomizes open innovation at its core existence, more research should focus on Malaysian fintech start-ups that are involved with the inflow and outflow of knowledge, as well as the creation of coupled innovation, all of which are aimed to expedite internal innovation and expand the use of innovation to external markets while benefiting the co-innovators in the process.

There is strong agreement in the innovation literature that firms monitor the changing needs, preferences and competences of their customers, competitors, suppliers, and other relevant stakeholders to develop unique and successful services (Danneels, 2002; Rubera, Ordanini \& Calantone, 2012). Dubbed as being market-oriented, extant literature has shown its critical effect towards innovation performance, and the positive relationship between market knowledge and innovation has been supported by sound empirical evidence (Atuahene-Gima, 1995; Han, Kim \& Srivastava, 1998; Sondergaard, 2005; Mavondo, Chimhanzi \& Stewart, 2005; Im, Hussain \& Sengupta, 2008). However, the study of this similar relationship has also been met with conflicting results following the contention that firms may end up being less innovative if they listen too closely to their customers and competitors, (Christensen \& Bower, 1996).

These variations in research findings may indicate that earlier researchers may have applied the "responsive" market orientation (Kohli and Jaworski, 1990; Narver and Slater, 1990), as opposed to 
the expanded "proactive" approach to market intelligence (Narver, Slater and MacLachlan, 2004), as concluded by Lamore, Berkowitz and Farrington (2013) who find that proactive market orientation displays a significant positive relationship with innovation performance, whereas responsive market orientation does not. It is contemplated that the proactive market orientation approach could be further enhanced with the introduction of FAOM, as an industry-specific association, in addition to existing market dimensions to assess the possible role that it plays in the country's open innovation activities to develop fintech services. In addition, there is also a convincing suggestion that the link between new product performance and market orientation may be exposed to potential indirect effects of other factors. It would be interesting to explore beyond extant research in Malaysia that has pondered on the roles of managerial ties (Naqshbandi \& Kaur, 2014) and trust (Nafi, Yusoff, Sam $\&$ Saad, 2015) toward open innovation process.

\section{Corresponding Author}

Misyer Mohamed Tajudin; Faculty of Business and Technology, UNITAR International University Malaysia; Corresponding e-mail: misyer64@unitar.my

\section{References}

Ahuja, G. (2000). The duality of collaboration: Inducements and opportunities in the formation of interim linkages, Strategic Management Journal, 21 (3), 317-343

Arrigo, E. (2018). Open Innovation and Market Orientation: An Analysis of the Relationship, Journal of the Knowledge Economy, Vol. 9:1, pp. 150-161.

Aspenberg, H. and Kumlin, A. (2012). Open innovation and organizational creativity - do they go together? A case study of the creative climate in an open innovation arena, Master of Science Thesis, Chalmers University of Technology Göteborg, Sweden, 2012 REPORT NO. E2012:047

Atuahene-Gima, K. (1995). An Exploratory Analysis of the Impact of Market Orientation on New Product Performance: A Contingency Approach, Journal of Product Innovation Management, 12 (September), pp. 275-93.

Baregheh, A., Rowley, J., \& Sambrook, S. (2009). Towards a multidisciplinary definition of innovation, Management Decision, 47(8), 1323-1339.

Barras, R. (1986). Towards a Theory of Innovation in Services, Research Policy, Vol.15, No.4, pp.16173.

Barras, R. (1990). Interactive Innovation in Financial and Business Services: the Vanguard of the Service Revolution, Research Policy, Vol.19, No.3, pp.215-37

Berg, L. and B. Naslund (eds.), (1988), Finansiella Innovationer, Stockholm

Carayannis, E.G. and Campbell, D.F. (2011) Open innovation diplomacy and a 21st century fractal research, education and innovation ecosystem: building on the quadruple and quintuple helix innovation concepts and the mode 3 production system, Journal of Knowledge Economy 2 (3), 327-372

Chesbrough, H. \& Brunswicker, S. (2013). Managing open innovation in large firms. Stuttgart: Fraunhofer Institute for Industrial Engineering. 
INTERNATIONAL JOURNAL OF ACADEMIC RESEARCH IN BUSINESS AND SOCIAL SCIENCES

Vol. 8, No. 9, Sept. 2018, E-ISSN: 2222-6990 @ 2018 HRMARS

Chesbrough, H. W. (2003). The Era of Open Innovation, MIT Sloan Management Review, 44(3), 35 41

Chesbrough, H. W. (2006). Open innovation: The new imperative for creating and profiting from technology, Harvard Business Press.

Chesbrough, H., \& Bogers, M. (2014). Explicating Open Innovation: Clarifying an Emerging Paradigm for Understanding Innovation, In H. Chesbrough, W. Vanhaverbeke, \& J. West (Eds.), New Frontiers in Open Innovation (pp. 3-28). Oxford University Press.

Christensen, C.M., \& Bower, J.L. (1996) Customer Power, Strategic Investment, and the Failure of Leading Firms, Strategic Management Journal, Vol. 17, No. 3 (Mar 1996), pp. 197-218

Christensen, J. F., Olesen, M. H., \& Kjaer, J. S. (2005). The industrial dynamics of Open Innovation-Evidence from the transformation of consumer electronics, Research Policy, Elsevier, vol. 34(10), pages 1533-1549, December.

Comin, D. (2014). Malaysia Beyond 2020. Malaysia: Penerbit UTM Press, Malaysia.

Dahlander, L. and Gann, D. (2010) How Open Is Innovation? Research Policy, 39, 699-709.

Danneels, E. (2002). The dynamics of Product Innovation and Firm Competencie, Strategic Management Journal, 23, pp. 1095-1121.

De Luca, L. M. and Atuahene-Gima, K. (2007). Market knowledge dimensions and cross-functional collaboration: examining the different routes to product innovation performance, Journal of Marketing, 71(1), 95-112.

De Smet, D., Mention, A. and Torkkeli, M. (2016). Involving high net worth individuals (HNWI) for financial services innovation, Journal of Financial Services Marketing, vol. 21, no. 3, pp. 226239

Duarte, V. and Sarkar, S. (2011). Separating the wheat from the chaff-a taxonomy of open innovation, European Journal of Innovation Management 14(4):435-459 - October 2011

Edwards, T., Delbridge, R. and Munday, M. (2005) Understanding Innovation in Small and MediumSized Enterprises: A Process Manifest, Technovation, 25, 1119-1127.

Enkel, E., Gassmann, O., \& Chesbrough, H.W. (2009). Open R\&D and open innovation: exploring the phenomenon, $\mathrm{R}$ \& D Management, 39

Ernst, D., (2006). Innovation Offshoring: Asia's Emerging Role in Global Innovation Networks (July 24, 2006). East-West Center, East-West Center Special Report \# 10, July 2006.

Fincham, R., Fleck, J., Procter, R., Tiemey, M., Williams, R. and Scarbrough, H. (1995). Expertise and Innovation. Information Technology Strategies in the Financial Services Sector, Oxford

Flores, R.L., Belaud, J.P., Le Lann, J-M. and Negny, S. (2015). Collective intelligence to solve creative problems in conceptual design phase, World Conference: TRIZ FUTURE, TF 2011-2014, Procedia Engineering 131 (2015) 850 - 860.

Fu, X. and Gong, Y. (2010). Indigenous and foreign innovation efforts and drivers of technological upgrading: evidence from China, World Development, 39(7): 1213-25.

Gadrey, J., Gallouj, F., Lhuillery, S., \& Weinstein, O. (1994). Innovation et $R$-D dans les services: des modalites originales, qui peuvent enrichir les conceptions industrielles, in Management of Services: A Multidisciplinary Approach, Proceedings of the 3rd International Research Seminar in Service Management, Aix-en-Provence

Gelis, P. (2016). Why Fintech banks will rule the world. Chichester, UK: John Wiley \& Sons, Ltd. 
INTERNATIONAL JOURNAL OF ACADEMIC RESEARCH IN BUSINESS AND SOCIAL SCIENCES Vol. 8, No. 9, Sept. 2018, E-ISSN: 2222-6990 @ 2018 HRMARS

Greco, M., Grimaldi, M. and Cricelli, L. (2016). An analysis of the open innovation effect on firm performance, European Management Journal 34 (2016) 501-516.

Han, J.K., Kim, N., \& Srivastava, R.K. (1998). Market orientation and organizational performance: is innovation a missing link? Journal of Marketing, 62(4): 30-35.

Herzog, P. and Leker, J. (2010). Open and closed innovation - different innovation cultures for different strategies, International Journal of Technology Management, 52.

Huete, L.M. and A.Roth. (1988). The Industrialization and Span of Retail Banking Units' Service, in R. Johnston (ed.). The Management of Service Operations, Kempstone (UK)

Huggins, R. and Thompson, P. (2015) Entrepreneurship, innovation and regional growth: A network theory, Small Business Economics, 45 (1), 103-128

Huizingh, E. (2010). Open innovation: State of the art and future perspectives, Technovation, 31.

Huston, L. and Sakkab, N. (2006). Connect and develop: inside Procter gamble's new model for innovation. Harvard Business Review, 84(3), 58-66.

Im, S., Hussain, M., and Sengupta, S. (2008). Testing interaction effects of the dimensions of market orientation on marketing program creativity, Journal of Business Research, 61(8), pp. 859-867.

Ismail, H.S., Yussuf, R.M., \& Zulkifli, N. (2017). Factors Influencing Implementation of Open Innovation Concept in Malaysian Industries, Journal of Advanced Management Science, Vol. 5, No. 1, pp. 35-39, January 2017

Kohli, A.K., and B.J. Jaworski. (1990). Market orientation: the construct, research propositions, and managerial implications, Journal of Marketing, 54 (April): 1-18.

Lamore, P.R., Berkowitz, D., \& Farrington, P.A. (2013), Antecedents of Proactive and Responsive Market Orientation, International Journal of Sustainable Strategic Management, Vol. 4, No. 1, 2-23

Langlois, R. N. (2003). The Vanishing Hand: the Changing Dynamics of Industrial Capitalism, Industrial and Corporate Change 12(2): 351-385.

Laursen, K. and Salter, A. (2006). Open for innovation: the role of openness in explaining innovation performance among U.K. manufacturing firms Strategic Management Journal, 27(2), 131-150

Lazzarotti, V. and Manzini, R. (2009). Different modes of open innovation: a theoretical framework and an empirical study, International Journal of Innovation Management, 13, 615-636.

Martovoy, A and Mention, A. (2016). Patterns of new service development processes in banking, International Journal of Bank Marketing, vol. 34, no. 1, pp. 62-77

Mathews, J.A. (2002). The Origins and Dynamics of Taiwan's R\&D Consortia. Research Policy 31(4), 633-651.

Mavondo, F. T., Chimhanzi, J., and Stewart, J. (2005). Learning orientation and market orientation: Relationship with innovation, human resource practices and performance. European Journal of Marketing, 39(11), pp. 1235-1263.

Miller, K., McAdam, R., Moffett, S., Alexander, A., \& Puthusserry, P. (2016). Knowledge Transfer in Quadruple Helix Ecosystems: An Absorptive Capacity Perspective, R \& D Management, 46(2), 383-399. 
INTERNATIONAL JOURNAL OF ACADEMIC RESEARCH IN BUSINESS AND SOCIAL SCIENCES Vol. 8, No. 9, Sept. 2018, E-ISSN: 2222-6990 @ 2018 HRMARS

Nafi, S.N.M., Yusoff, R.Z., Sam, T.L. \& Saad, R. (2015). Open Innovation Among SMEs in Malaysia: The Issue of Trust, International Academic Research Journal of Business and Technology 1(2) 2015 Page 165-174

Naqshbandi, M. M., \& Kaur, S. (2011). Factors Affecting Open Innovation : Evidence from Malaysia, Australian Journal of Basic and Applied Sciences, 5, 2783-2795.

Naqshbandi, M.M., \& Kaur, S. (2014). Do managerial ties support or stifle open innovation?, Industrial Management \& Data Systems, Vol. 114 Issue: 4, pp.652-675

Narasimhan, O., Rajiv, S. and Dutta, S. (2006). Absorptive capacity in high-technology markets: the competitive advantage of the haves, Marketing Science, 25(5), 510-524.

Narver, J. C., and S. F. Slater. (1990). The effect of a market orientation on business profitability, Journal of Marketing, 54 (October): 20-35

Narver, J.C., Slater, S.F., and MacLachlan, D.L. (2004). Responsive and Proactive Market Orientation and New Product Success, The Journal of Product Innovation Management, 21, pp. $334-347$.

Naslund, B. (1986). Financial Innovations. A Comparison with R\&D in Physical Products, EFI Research Paper/Report, Stockholm.

National Survey of Innovation 2012, MOSTI (www.mastic.gov.my)

National Survey of Innovation 2015, MOSTI (www.mastic.gov.my)

Ollila, S. and Elmquist, M. (2011). Managing Open Innovation: Exploring Challenges at the Interfaces of an Open Innovation Arena. Managing Open Innovation, 20, 273-283.

Popa, S., Soto-Acosta, P. and Martinez-Conesa, I. (2017) Antecedents, moderators, and outcomes of innovation climate and open innovation: An empirical study in SMEs, Technological Forecasting and Social Change, Vol. 118, pp. 134-142.

Reibstein, D.J., Day, G., \& Wind, J. (2009). Guest Editorial: Is Marketing Academia Losing Its Way? Journal of Marketing: July 2009, Vol. 73, No. 4, pp. 1-3.

Reidenbach, R. and Grubbs, M. (1987). Developing New Banking Products, Englewood Cliffs

Reidenbach, R.E. and Moak, D.L. (1986). Exploring retail bank performance and new product development: A profile of industry practices, Journal of Product Innovation Management, Volume 3, Issue 3, September 1986, Pages 187-194

Rigby, D. and Zook, C. (2002). Open-Market Innovation. Harvard Business Review, 80, 80-93.

Rubera, G., Chandrasekaran, D. and Ordanini, A. (2016). Open innovation, product portfolio innovativeness and firm performance: the dual role of new product development capabilities, Journal of the Academy of Marketing Science 44: 166-184

Rubera, G., Ordanini, A. and Calantone, R. (2012). Whether to integrate R\&D and marketing: the effect of firm competence. Journal of Product Innovation Management, 29(5), 766-783.

Smedlund, A. and Toivonen, M. (2007). The role of KIBS in the IC development of regional clusters, Journal of Intellectual Capital, Vol. 8 (1), 159-170

Sondergaard, H. A. (2005). Market-oriented new product development: How can a means-end chain approach affect the process? European Journal of Innovation Management, 8(1), pp. 79-90.

Spithoven, A., Vanhaverbeke, W., \& Roijakkers, N. (2013). Open innovation practices in SMEs and large enterprises, Small Business Economics, 41(3), 537-562.

Storey, C. and Easingwood, C. J. (1999). Types of New Product Performance: Evidence from the Consumer Financial Services Sector, Journal of Business Research 46, 193-203 (1999) 
INTERNATIONAL JOURNAL OF ACADEMIC RESEARCH IN BUSINESS AND SOCIAL SCIENCES

Vol. 8, No. 9, Sept. 2018, E-ISSN: 2222-6990 @ 2018 HRMARS

Sundbo, J. (1991). Market Development and Production Organisation in the Financial Service Firms of the 1990s, Scandinavian Journal of Management, Vol.7, No.2, pp.95-110

Sundbo, J. (1994). Modulization of Service Production, Scandinavian Joumal of Management, Vol.10, No.3, pp.245-66.

Sundbo, J. (1997). Management of Innovation in Services, The Service Industries Journal, Vol.17, No.3 (July 1997), pp.432-455

Trott, P., \& Hartmann, D. (2009), Why 'Open Innovation' Is Old Wine In New Bottles, International Journal of Innovation Management (ijim), 13, (04), 715-736

Usman, M., Roijakkers, N., Vanhaverbeke, W., \& Frattini, F. (2018). A Systematic Review of the Literature on Open Innovation in SMEs, In: Vanhaverbeke, W., Frattini, F., Roijakkers, N., \& Usman, M. (ed), Researching Open Innovation in SMEs, (pp. 3-35), World Scientific Publishing, New Jersey.

Van de Vrande, V., De Jong, J.P., Vanhaverbeke, W. and De Rochemont, M. (2009). Open innovation in SMEs: trends, motives and management challenges, Technovation 29(6), 423-437

Vanhaverbeke, W., Gilsing, V., \& Duysters, G. (2012). Competence and Governance in Strategic Collaboration: The Differential Effect of Network Structure on the Creation of Core and Noncore Technology, The Journal of Product Innovation Management, Volume29, Issue5, September 2012, Pages 784-802

VonHippel, E. (2005). Democratizing innovation, Cambridge: MIT Press.

Vorhies, D.W. and Morgan, N.A.(2005). Benchmarking NPD capabilities for sustainable competitive advantage. Journal of Marketing, 69(1), 80-94.

West, J. and Gallagher, S. (2006). Challenges of open innovation: the paradox of firm investment in open-source software. R\&D Management, 36(3), 319-331.

West, J., Vanhaverbeke, W. and Chesbrough, H.(2006). Open innovation: A research agenda, In H. Chesbrough, W. Vanhaverbeke, \& J. West (Eds.), Open innovation: Researching a new paradigm (pp. 285- 209). Oxford: Oxford University Press.

Xiaolan Fu, Hongru Xiong, (2011). Open innovation in China: policies and practices, Journal of Science and Technology Policy in China, Vol. 2 Issue: 3, pp.196-218,

Yoon, S.-J. and Lee, S.-H. (2005). Market-Oriented Culture and Strategy: Are They Synergistic? Marketing Bulletin, 16, 1-20.

Ystrom, A, Aspenberg, H. and Kumlin, A. (2012). What's creative about open innovation? A case study of the creative climate in an open innovation arena, Conference: 13th International CINet Conference, Rome, 16-18 Sept, 2012

Yström, A., Ollila, S., Fredberg, T. \& Elmquist, M. (2010). Communities of Practice for Open Innovation - Enabling Organizational Creativity? ICICKM - 7th International Conference on Intellectual Capital \& Knowledge Management, Hong Kong. 